\title{
The Issue of Unveiling the Aurah for Women in Quran: A Critical and Contextual Analysis of Surah an-Nūr [24]: 58-61)
}

\author{
Moh. Nailul Muna \\ Universitas Islam Negeri Syarif Hidayatullah Jakarta, Indonesia \\ m.nailulmuna7@gmail.com
}

\section{Article Information}

Submitted: Augustus, 19, 2021

Revised: September, 09, 2021

Accepted: November, 11, 2021

\section{Keywords}

Women's Aurah; Aurah Cover; Munasabah.
Kata Kunci

Aurat Wanita; Penutup Aurat; Munasabah.
Abstract

The study of aurah has reaped many polemics from time to time, this is based on the fact that the Qur'an does not provide explicit information about the extent to which the aurah must be covered. In response to this, the scholars can be divided into two groups, the first is those who are strict in setting the limits of aurah on the historical manner. Meanwhile, in the other group, figures such as Syahrur gives freedom within deciding the limits of woman's aurah according to the minimum and maximum limits. One of the reasons held by the second group in covering aurah term is that it could cause the difficulty or masyaqqah. In response to that, this paper aims to bridge the gap based on (QS. an-Nür [24]: 60) which contains the permissibility for qawāid minan nisā' to reveal his outer clothing. Through the linguistic approach which is relation of text belongs to Salwa MS El-Awa. The application of this method considers the aspects of coherence and relevance in the text. The result appeared that religion actually allows an old or young woman who has not charm or attraction to be able to open her khimār, niqāb and ridā' on condition that has experienced menopause, has lost his lust, and does not intend to show jewelry, and she is in a private sphere; home.

\section{Abstrak}

Kajian tentang aurat menuai banyak polemik dari masa ke masa, hal tersebut dilandasi karena al-Qur'an tidak memberikan keterangan eksplisit tentang sampai batas mana aurat seseorang harus ditutupi. Menyikapi hal tersebut, para ulama dapat dibagi ke dalam dua 
kelompok, pertama mereka yang bersikap ketat dalam menetapkan batasan aurat dengan landasan riwayat. Sedangkan di kubu yang lain, tokoh-tokoh semisal Syahrur memberikan kebebasan dalam batasan aurat sesuai batas minimal dan batas maksimalnya. Salah satu argumen dari kelompok kedua ini bahwa menutup aurat dapat memunculkan masyaqqat. Menyikapi hal tersebut, tulisan ini bertujuan untuk menjembatani kesenjangan yang ada dengan berlandaskan (QS. an-Nūr [24]: 60) yang berisi kebolehan bagi qawāid minan nisā' untuk menyingkap pakaian luarnya. Melalui pendekatan linguistik relasi teks milik Salwa MS El-Awa yang dalam aplikasinya mempertimbangkan aspek koherensi dan relevansi yang berada dalam teks, ditemukan bahwa sebenarnya agama membolehkan seorang wanita tua maupun muda yang sudah tidak menarik lagi untuk bisa membuka khimār, niqāb dan ridā' dengan syarat sudah mengalami menopause, sudah hilang syahwatnya, dan tidak bermaksud menampakkan perhiasan, dan berada dalam ruang-lingkup privat; rumah.

\section{Introduction}

One of the cases that needs to be further highlighted is the permissibility of removing outer wear referred to qawā 'idu minan nisā' (QS. 24: 60). The existence of religious legalization regarding unveiling aurah for certain groups is less highlighted by the fiqh scholars. Even, the tendency is more emphasize and strengthen the determination of the aurah limits to women than conciliate to the reality. For instance: Shaykh Muhammad Ali as-Shobuni representing classical idea states that the level of the obligation to wear the hijab for women is the same as the level for prayer and fasting, and whoever leaves it while denying his obligations, he is punished as an apostate or leaving Islam based on hijā $b$ verses. ${ }^{1}$ On another side, Syahrur representing contemporary idea on the hija $\bar{b}$ interpretation, is more courageous when interpreting the cover and limits of aurah. He stated that the minimum limit forwomen's clothes is satr al-juyūb (QS. 24: 31) or covering the chest (breast), genitals, and not completely naked. The maximum limit is to cover

${ }^{1}$ Muhammad Ali as-Shobuni, Rawāi'ul Bayān; Tafsīr Ayat alAhkām, vol. 3 (Damascus: Maktabah al-Ghazāli, 1980), 380. the entire body, except the two palms and face. ${ }^{2}$

Knowing with the reality of two tendencies talking about the aurah limits, it seems neglect the allowed verse of unveiling aurah by a condition (Surat al-Nūr [24]: 60).

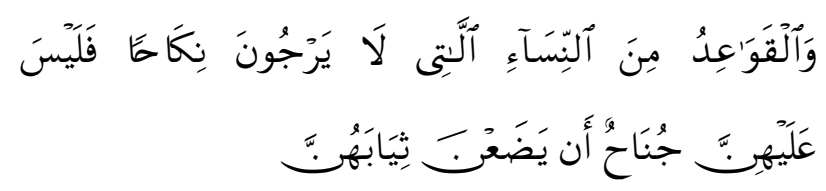

That verse is clearly pointing to the legalization of unveiling aurah, but all of the discussion hardly discuss about that's matter. Then, the contextual interpretation in this verse can link two contradiction argument between classical by holding tradition source and modern idea by holding rational source in limiting aurah; This term is part of the human body both men

\footnotetext{
${ }^{2}$ With this approach, women who do not wear the hijab based on current habits have actually fulfilled Allah's provisions, because they are still in the area between the minimum and maximum limits. On the other hand, a woman who covers her whole body (including her face, with a veil for example) is considered to have come out of the hudûd al-a"lâ (maximum limit) that has been set by Allah, because it exceeds the maximum limit determined by the Qur'an. This means that women who wear the veil and cover their entire body -with this approach- are actually "un-Islamic". Muhammad Syahrûr, Nahwa Ushul Jadīdah li al-Fiqh al-Islāmy (al-Ahāli: Mesir, 2000), 331; see also; al-Kitâb wa al-Qur'ân; qirâah mu'âshirah (Egypt: al-Ahâli, 1992), 33-34.
} 
and women that should not be shown to others, mahram and husband in exception. ${ }^{3}$ From this definition, when juxtaposed with human nature, both male and female, it has negative nuances. Then, aurah is a human defect that is not worthy to be displayed.

The limits of aurah becomes very important when it is connected to the problem of religious norms, especially when it comes to religious rituals in Islam, such as prayer. The Islamic law's scholars have directly explained that the aurah of men starts from the navel down to the knees. ${ }^{4}$ As for women, all parts of the body are aurah except the face and the palms of the hands. ${ }^{5}$ Even if it is referred to in the Qur'an, it has been explicitly explained which parts must be covered but not as strictly as the classical scholar's provisions, the Qur' an only warns that women "cover their aurah and do not reveal their jewelry except which (usually) appears from him. And let them cover their khumūr..." (QS. 24: 31). So, it can be said that strict aurat restrictions are something that is usually done by the old scholars (ijtihad) and of course it is necessary to contextualize or re-read the provisions that have been in effect.

Thus, this paper aims to examine the permissibility of unveiling aurah and review the conditions required before applying the verdict. Hopefully, this effort can bridge the gap that is so visible between classical scholars and contemporary scholars, by promoting a moderate attitude. However, as the initial basis of this paper, it will still look at the mainstream view of the aurah limits, both outside and inside prayer, for them; free women and slaves. The difference commonly comes when wholly looking to Madzāhibul 'Arba'ah; Imam Hanafi explains: All parts of woman's body are aurah, only face, palm, and sole. Imam Maliki claims: All parts of

\footnotetext{
${ }^{3}$ Ibid., 5 .

${ }^{4}$ The law is based on a hadith narrated by Abu Bakr: The Prophet SAW said: "A man's nakedness is from the navel down to two knees" (HR. Abu Bakr. See: Abdul Mannan, Fiqih Lintas Madzhab, volume 1 (Kediri: PP. Al-Falah, 2009), 91. ${ }^{5}$ Ibid., 91.
}

woman's body are aurah except face and palm only. Imam Syafi'i has the same idea with Imam Maliki regarding a freedom woman. The last one is Imam Hanbali who has not any difference idea with Imam Maliki. ${ }^{6}$ This difference among madzhāb will not get a large portion in this study.

The urgency of this study can be further seen through three aspects: First, the religious aspect. It is undeniable that religion has provided guidance to cover aurah with provisions based on the qath'iy argument (QS. 24: 31). The implication is that the command to cover aurah means an obligation to be applied absolutely to mukallaf. But at the same time, Islam also provides direction that some groups are allowed to take off their outerwear. This term shows that Islam is not rigid and considers the conditions experienced by muslim.

Second, social aspects. Following the command to cover aurah with very strict conditions, in some circumstances it gives a burden to women. Especially, if it is associated with certain jobs outside the home, having the ability to open some of their body coverings can ease the women's movement in the modern era, for example when it comes to the profession related with village condition where most of them are farmers, who work in gardens and rice fields. We cannot find this phenomenon culturally with what is in Arabia. Therefore, it is not surprising that woman's aurah cannot be covered normally when she is in a muddy field or when processing seafood brought by her husband. Thus knowing the legalization can discover a new horizon of the Islam flexibility to those need to be flexible in their neighborhood.

Third, academic aspect. Studies or discussions that allow opening some parts of the aurah are still rarely found. In general, the study that involves aurah revolves around three categories: (1). The category that emphasizes the command

${ }^{6}$ Syarkawi, "Studi Kritis Terhadap Pemikiran M. Quraish Shihab Tentang Aurat Wanita dan Jilbab yang Bertentangan dengan Empat Mazhab," Journal Al-Qira'ah 14, no. 2 (2020): 13-15. 
to cover women's aurah. Some examples in this first category are: al-aurah fi fiqhi al-Islami wa ațaruha fil hayātid diniyyah wal ijtimaiyyah. ${ }^{7}$ (2). The category that reviews the limits of aurah for women, such as: Muhammad Syahrur, alKitāb wal Qur'ān: Qirā 'ah Mu'āșirah. ${ }^{8}$ (3). The category that discusses clothes covering aurah, namely The concept of aurah: Islamic dressing code and personal grooming according to fiqh law, ${ }^{9}$ The Veil Unveiled; The Hijab in Modern Culture, ${ }^{10}$ Redefining Hijab: American Muslim Women's standpoints on veiling. ${ }^{11}$ Through these three main clusters, it is also shown that in general, the topic of "the permissibility of opening aurah" is rarely touched by the scholar, and in particular when referring to (QS. 24: 60) as the object of this study. Thus, it can be seen two things, how the study is going to work and what it may offer further (novelty), both in terms of topic and object of study.

All scholars across generations nearly agree that the study of the Qur'an should not be done partially although this does not mean having to abandon the atomistic dimension in their research. Therefore, the method that cannot be ruled out in this case is the munasabah or correlation method. Indeed, the search for relations between verses can be a guide for researchers, not only useful for obtaining comprehensive meaning, but also limiting manner in order to make the discussed object is intertwined well from the referred topic. Regarding this effort, the scholars have

\footnotetext{
${ }^{7}$ Nurul Hikmah binti Nidzam, al-aurah fi fiqhi al-Islami wa atsaruha fil hayātid diniyyah wal ijtimaiyyah, Dissertation, University Islam Sultan Sharif Ali, Faculty of Syari'ah and Islamic law (2020).

${ }^{8}$ In this work, Syahrur has her own concept of the limits of women's genitalia based on the construction of the hudud theory. See: Muhammad Syahrur, al-Kitāb wal Qur'ān: Qirā'ah Mu'āṣirah (Damascus: al-Ahaly, 2013).

${ }^{9}$ Zanirah Mustafa, et.al., "The concept of aurah: Islamic dressing code and personal grooming according to fiqh law", E-Academia Journal 7, no. 2 (2018).

${ }^{10}$ Tabassum F. Ruby, "The Hijab in Modern Culture," Woman's Studies Internasional Forum 29, no. 1 (2006)..

${ }^{11}$ Rachel Anderson Droogsma, "Redefining Hijab: American Muslim Women's standpoints on veiling," Journal of Applied Communication Research 35, no. 3 (2007).
}

already tried to discuss each section topic, but in reality there are still many differences, due to the obscurity in reading relationship among the verses. $^{12}$

The method used by this work in order to reveal the meaning contained in the object of this study is to use a text relation linguistic approach belonging to Salwa MS El-Awa which in its application considers the aspects of coherence and relevance in the text. The meaning of the coherence aspect here is related to everything that is in the text, or something that has to do with grammar. For example: Phrases and elements in the text, pronouns, conjunctions, etc. ${ }^{13}$ The study of coherence relationships focuses on the formal relationship between the main body of the text and the important components in the text.

Meanwhile, the study of the relational relevance is not only focused on the expressions spoken in the Qur'an, but also related to the assumptions, information, ideas and thoughts contained in the text. This aspect will be able to unite separate expressions in the aspect of coherence. ${ }^{14}$ It also provides a more comprehensive understanding of the text being studied. ${ }^{15}$ Moreover, this study focuses on pragmatic or relevance aspects by considering grammatical aspects, and if it is existed a discrepancy between the coherence and relevance relationships, then this study wins the relevance relationship.

The way how this method works in this study is to look carefully at munāsabah that extended on two main parts. First, the coherence. Second, the relevance aspect of (QS. 24: 60) including the verses that surround it (Qs. 24: 58, 59, and 61). In practical, the coherence relations can be in the form of searching the conjunction letters in these verses, or searching for other grammatical

\footnotetext{
${ }^{12}$ This is also what Salwa alluded to before he divided surah al-Qiyāmah. See: Salwa MS. El-Awa, Textual Relations in the Qur'an; Relevance, Coherence, and Structure (London and New York: Routledge 2006), 103.

${ }^{13}$ Ibid., 26.

${ }^{14}$ Salwa MS. El-Awa, Textual Relations in the Qur'an..., 26.

${ }^{15}$ Ibid., 28.
} 
aspects that may be an indication of a relationship with other verses. Meanwhile, the relevance aspect focuses on the main themes in these verses, as well as looking at the main ideas and information. These ideas are then put together and read comprehensively with a narrative of the permissibility of unveiling aurah based on (QS. 24: 60). The discovery of the coherence relation and relevance that is about (QS. 24: 60) is expected to provide a complete understanding of unveiling aurah's concept in the verse. And then it can be the foundation for contextualization efforts in the modern era.

\section{Description of (QS. 24: 60) and its historical aspects}
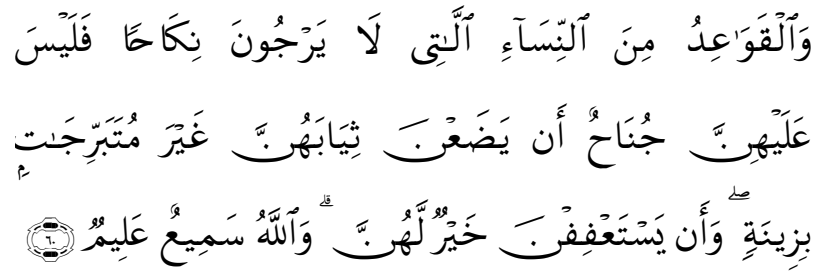

"And women of post-menstrual age who have no desire for marriage - there is no blame upon them for putting aside their outer garments [but] not displaying adornment. But to modestly refrain [from that] is better for them. And Allah is Hearing and Knowing" (QS. an-Nūr [24]: 60).

Surah an-Nūr is a part of madaniy surah, the group of surah was revealed in Medina city or post-hijrah, that there is no dispute in it. ${ }^{16}$ This implies that this verse was revealed in conditions where the Muslim community was already established in Medina. More details can be seen through the aspect of $a s b \bar{a} b$ al-nuzūl (the reasons behind revealed verse).

According to as-Suddi, a group of verses (QS .24: 58, 59, and 60) were revealed regarding:

"a group of Rasulullah's companions who preferred to have marital relations at three

\footnotetext{
${ }^{16}$ Badruddin Muhammad bin Abdullah az-Zarkasyi, Al-Burhān fì
} Ulūmil Qur'ān (Kairo: Dārut Turaș), 194. times; First, before the dawn prayer. Second, night. Third, after isha'. They have sexual intercourse then take a bath and pray. But on those three occasions, slaves and their children were released from entering the house without permission" (HR. Abu Dawud). ${ }^{17}$

Whereas in the following verse (QS. 24: 61), it has asbāb al-nuzūl which is based on Aisyah's explanation.

"Aisha narrated that when they wanted to do jihad with Rasulullah saw, the Muslims handed the keys to their houses to their family or relatives who did not participate in the jihad. They said, "All the food in the house, you are free to enjoy," but the family or relatives who were assigned the task of taking care of their house refused and said, "We will not enjoy the food, because they do not give it with a sincere heart." Then Allah revealed this verse" (HR. Bazzar). ${ }^{18}$

\section{Munasabah al-Ayāh (QS. 24: 58, 59, 60 and 61)}

Some interpreters often classify this verse with the previous two verses, namely (QS. 24: 58), and (QS. 24: 59). And sometimes it is associated with a verse after it, namely:

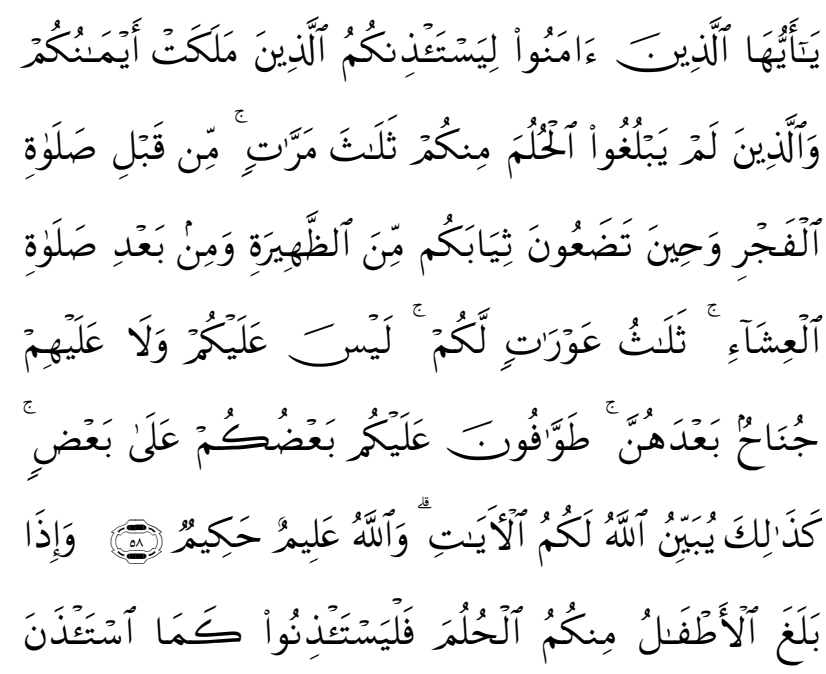

${ }^{17}$ Penerbit Kalim, Al-Qur'an Tafsir Per Kata Tajwid dan Kode Angka al-Hidayah (Tangerang Selatan: Kalim, 2011), 359.

${ }^{18}$ Ibid., 359. 


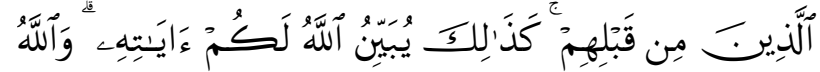

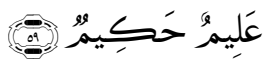

"O you who have believed, let those whom your right hands possess and those who have not [yet] reached puberty among you ask permission of you [before entering] at three times: before the dawn prayer and when you put aside your clothing [for rest] at noon and after the night prayer. [These are] three times of privacy for you. There is no blame upon you nor upon them beyond these [periods], for they continually circulate among you - some of you, among others. Thus does Allah make clear to you the verses; and Allah is Knowing and Wise (58). And when the children among you reach puberty, let them ask permission [at all times] as those before them have done. Thus does Allah make clear to you His verses; and Allah is Knowing and Wise" (59) (QS. an-Nūr [24]: 58-59).
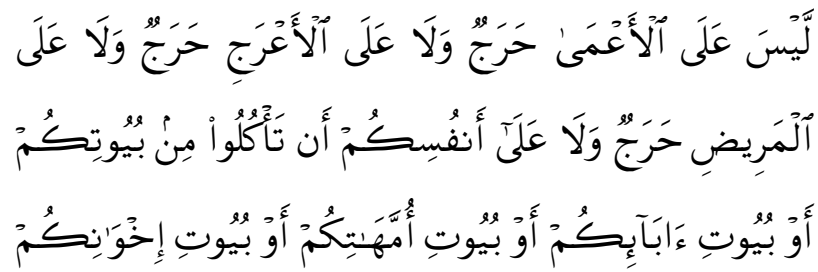

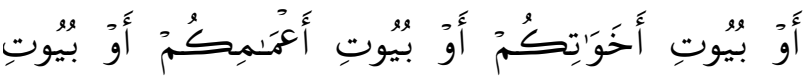
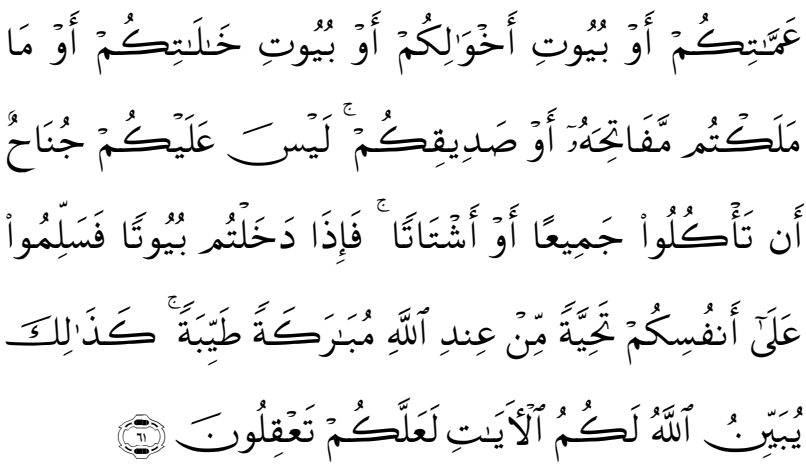

"There is not upon the blind [any] constraint nor upon the lame constraint nor upon the ill constraint nor upon yourselves when you eat from your [own] houses or the houses of your fathers or the houses of your mothers or the houses of your brothers or the houses of your sisters or the houses of your father's brothers or the houses of your father's sisters or the houses of your mother's brothers or the houses of your mother's sisters or [from houses] whose keys you possess or [from the house] of your friend. There is no blame upon you whether you eat together or separately. But when you enter houses, give greetings of peace upon each other - a greeting from Allah, blessed and good. Thus does Allah make clear to you the verses [of ordinance] that you may understand" (QS. an-Nūr [24]: 61).

The theme raised in the group of 4 verses (QS. 24: 58, 59, 60, 61) is "House Rules" (Islamic ethics). ${ }^{19}$ Whereas in another position, the relationship of three verses 58,59. 60 is interpreted by Hasby as-Shiddiqy as containing the issue of licensing to children and slaves, as well as discussing the permissibility of undressing. ${ }^{20}$ Meanwhile, in Shaykh Ali as-Shobuni's ahkam al-Qur'an interpretation, three verses (QS. 24: $58,59,60)$ are included in the discussion topic of al-isti'zān fí auqātil khalwah (permission in quiet times). ${ }^{21}$ So, the relationship that is built here from these verses is a matter of ethics in a family, especially if you look at verses (QS. 24: 58 and 59). Entering verse 60, although the verse (QS. 24: 58) discusses the genitals, while the verse (QS. 24: 60) discusses undressing, but the aurat referred to in (QS. 24: 58) is not genitalia in the sense of body parts that must be covered, but the meaning of closed, or veiled times, while at (QS. $24: 60)$ relates to something that is attached to the

\footnotetext{
${ }^{19}$ Abdulkarim Amrullah, Tafsir al-Azhar, vol. 7 (Singapura: Pustaka Nasional, 1989), 4971.

${ }^{20}$ Teungku Muhammad Hasbi ash-Shiddiqy, Tafsir al-Qur'an alMajid; an-Nur, vol. 4 (Semarang: Pustaka Rizki Putra, 2000), 2851.

${ }^{21}$ Muhammad Ali As-Shobuni, Rawāi'ul Bayān; Tafsīr Ayat alAhkām, vol. 3 (Damaskus: Maktabah al-Ghazali, 1980), 201.
} 
female body and needs to be covered. ${ }^{22}$

Furthermore, munāsabah as-suwār either an-Nūr to al-Furqān or al-Nūr to al-Mu'minūn is quite interesting. Ibn Asyūr argues that an-Nūr mainly contains about the law and demand of interaction between a woman and man. Moreover, Rasulullah has ever ordered his companions to teach this surah to their families. Thus, an-Nūr can be devoted with the interaction between a woman and man in family scope. The principle purpose of the theme related with the previous surah almu'minūn, is explaining about the happiness and victory awarded to mu'minūn. Another view describes that this surah is the allurement to believe in God and hereafter, and also describes a believer nature and unbeliever nature. ${ }^{23}$ The last correlation is linked with an-Nūr and al-Furqān as a proceeding surah. "al-Furqān" means "the separates between the goodness and badness, and it is claimed as a part of Makkiyah - the surah has been revealed in Makkah period or Makkah place-whereas an-Nūr is Madaniyah; This surah has been revealed in Madinah either time or place meaning. Eventhough, al-Mu'minūn is Makkiyyah, thus an-Nūr is hemmed by Makkiyyah surah. $^{24}$

So, instead of taking surah munasabah as the main idea. It will be better to take the discussion on the munasabah al-ayāh as a main approach to identify the hide value behind the text. And it will be started by identifying language on the text. Salwa MS El-Awa method hugely assists this study because of considering the aspects of coherence and relevance in the text. The meaning of the coherence aspect here is related to everything that is in the text, or something in grammatical case. For example: Phrases and elements in the text, pronouns, conjunctions, etc.

\footnotetext{
${ }^{22}$ Ibrahim Madkur, Mu'jām Alfāz Al-Qur'an al-Karīm (Kairo: Ihya'a at-Turāș,1988),804.

${ }^{23}$ M. Quraish Shihab, Tafsir Al-Mishbah, vol. 3 (Jakarta: Lentera Hati, 2005). 134.

${ }^{24}$ Hasby Shiddieqy. Tafsir Al-Quran Al-Majid An-nur, vol. 3 (Semarang: Pustaka Rizki Putra, 2000). 2721.
}

\section{Language Analysis on (an-Nür [24]: 60)}

Talking about language analysis, the author will exclude explaining all the words contained in (QS. 24: 60). The author will only explore words that feel vague, such as qawā'id, yadha'na, șiyāb, mutabarrijāt, and zinah.

The term al-qawa'idu based on the oldest dictionary, lisānul arab, comes from the word qa'ada or qa' 'idah which means ussi, it means "foundation". Then, the term qawāid mean sal-isās. It is said that qawāidul baiti has same meaning like "the foundation of the house". That is related with (QS. 2: 127) which talks about the Prophet Ibrahim who left the foundation of the Baitullah. Whereas the word qa'ada linked with women in the nature, this word automatically means"disconnected". If it is said: qa'adati al-mar'ah 'an al-haid wa al-walad, it means: the woman neither experiences haid nor togets pregnant again. Then, based on the grammatical aspects that existed at that time, the word qawa' $i d$ was an inherent trait of women, not men. This trait can also refer to old and aged women. ${ }^{25}$ The next word وضع which means "to put" or "put". لاخمار عليها و واضع "It sith the meaning (woman) who does not wear a head covering. ${ }^{27}$

While the word ثَبَابَهُنَ or siyāb has a form equivalent to $a s ̦ w a \bar{b} b$ which is singular șaubun, namely clothing. The word siyāb also has a synonym with the word libās. The word siyā is often associated with the sense of human. In addition, it can also be attributed to a human's behavior. Therefore, it can be said that "his clothes are so dirty because his actions are bad". On the other hand, it can be said that the clothes are good when he purifies his heart and is free from bad attitude and deeds. Meanwhile, in the context of clothing, the word siy $\bar{a} b$ is often associated with three things, first $i z \bar{a} r$, second

\footnotetext{
${ }^{25}$ Ibn Manzur, Lisānul Arab (Kairo: Dar Ma'arif, 1119), 3689. ${ }^{26}$ Ibid., 4857.

${ }^{27}$ A. W. Munawwir, Kamus al-Munawwir Arab Indonesia Terlengkap (Surabaya:Pustaka Progressif,1997), 1565.
} 
ridā', third, qamīs. ${ }^{28}$

The word mutabarrijat is derived from barujathat means"everything that is visible". Therefore, it is said burūj because of its appearance and clarity. When it is said tabarruju beside the female conotation, it means "a woman who shows her jewelry and beauty to men". In addition, tabarrajāt mar'ah can also mean "showing his face". Ghoira mutabarrijāt bi zinah, the word tabarruja in the phrase means "it seems like jewelry that can attract male lust". Then, the word tabarruj only applies when showing jewelry to ajnabiy or non-mahram. ${ }^{29}$

In conclusion, the word bi zinah indicates the meaning of all things that beautify someone. In relation to aurah, it can be in the form of anklets, necklaces, and bracelets. ${ }^{30}$

\section{The interpretation of the scholars on (QS.}

\section{4: 60)}

The legal position of (QS. 24: 60) cannot be contested, even though there are other verses that seem to contradict this, at (QS. 24: 31) which ordered to cover aurah and also (QS. 33: 59) which ordered to cover the veil. If you look closely between the verses (QS. 24: 60) and (QS. 24: 31), (QS. 33: 59). Seeming contradictory, the last two verses command to cover aurah by wearing clothes and hijab. While in (QS. 24: $60)$ it is even permissible to undress. In placing the position of the qawā'id minan nisā' verse, it is necessary to consider the position of the other two verses. Responding to the existence of verses that "seem" contradictory, the scholars have formulated several ways to deal with the problem in ta'arud discussion. Among them, with the concept of naskh, tarjihh, amm, khass, istitsnā', etc. These concepts can also be applied in (QS. 24: 60). This verse seems to contradict the two paragraphs above. If you refer to the interpretation of ibn Kathir, it has been explained

\footnotetext{
${ }^{28}$ Ibn Manzur, Lisānul Arab ..., 519-520.

${ }^{29}$ Ibid., 242-243.

${ }^{30}$ Ibid., 1903.
}

that the solution between (QS. 24: 31) and (QS. 24: 60) is fixed by naskh (abrogation). But the text here does not mean abrogation, limitation or deleting rather istisna ' (exception) where this verses has specialized of other verses talk about covering aurah. Where verse (QS. 24:60) has specified and excluded from the provisions of the verse (QS. 24: 31), it is based on a narration from Ibn Abbas. ${ }^{31}$

According to the earliest generation of interpreters that can still be found their works, Imam Muqatil bin Sulaiman, highlights the main phrases of the verse. What is meant by wal qawā'id minan nisā' is an old woman who is no longer menstruating. Then, the woman do not want to get married. Thus, she is not sinful to apply this verse, 'an yadha'na tsiyābahunna, interpreted by Muqatil as the permission to remove the hijāb. Meanwhile, the hijāb referred to by Muqatil is a covering that exceeds the limit of khimār (sheath). ${ }^{32}$

The next interpreter, Imam at-Tabari, provides clearer information regarding the category of women referred to by the verse, in addition to women who are not menstruating, at-Tabari also includes women who are no longer able to give birth. Meanwhile, the phrase 'an yadha'na tsiyābahunna interpreted by Imam at-Thabari as same as Muqatil does means hijāb, but with the addition of the term qina $\bar{a}^{\prime}$ where both mean veils with less area covered than khimār. To clarify these differences, the author will convey in the discussion about aurah cover. Furthermore, the interesting aspect related with the interpretation of Imam at-Tabari about allāti lā yarjūna nikāhan, which refers to yaisna minal bu'ūlah (women who are desperate to get a husband), and he also does not expect to have a husband. ${ }^{33}$ Build upon author's opinion, the explanation of "unwilling

\footnotetext{
${ }^{31}$ Ismail bin Umar bin Katsir al-Qursy, Tafsìr al-Qur'ānul Adzīm (Beirut: Dar ibn Hazm, 2000), 1346.

${ }^{32}$ Muqatil bin Sulaiman, Tafsīr Muqātil bin Sulaiman, vol. 3 (Beirut: Muassasah Tarikh al-Araby, 2002), 208.

${ }^{33}$ Ibn Jarir at-Thabari, Jamīul bayān 'an Ta'wīl al-Qur'ān, vol. 5 (Beirut: Muassasah ar-Risālah), 446.
} 
to marry" through the word yaisna (desperating women) instead opens a longer discussion about what factors causing a woman to give up on getting married. But for this point, we will suffice until here, and will be continued in the next section.

Turning to the interpretation in the next era, ibn Katsir agrees with the explanation of the previous interpretation of who is meant by the Qur'an by the qawä 'idu minan nisā'. It refers to women who are no longer menstruating, and also can not give birth. While the additional condition, lā yarjūna nikāhan, refers to women who no longer have the passion to marry. Futhermore, the clothes that can be removed in the phrase yadha'na șiyābahunna are jilbāb or ridā'. In the contrary, Abu Salah explains that the outerwear can be removed but we are going to further by wearing more closed clothes, such as protective clothing and khimār (veils). Meanwhile, according to said bin Jubair, it is permissible to take off the outerwear when the time is quiet. ${ }^{34}$

Imam al-Qurtuby agreed with the opinion of the previous scholars regarding the meaning of qawa' $i d$, but there is an interesting information that is based on Rabi'ah that what is meant by qawāid minan nisā' is a woman who looks dirty, and filthy because she is so old. This explanation can be used as a basis for seeing the purpose of the verse which actually focuses on the "attractiveness" and "passion" aspects. In the following phrase, the sentence is fa laisa 'alaihinna junahun an yadha'na siyābahunna ghaira mutabarrijātin bi zinah. According to al-Qurtuby, it is only intended for women, and cannot be applied to men. Therefore it can be said with this argument, women were specially gifted law excluding others. ${ }^{35}$

Hamka, one of most Indonesian renowned and

\footnotetext{
${ }^{34}$ Ismail bin Umar bin Katsir al-Qursy, Tafsìr al-Qur'ānul Adzīm (Beirut: Dar ibn Hazm, 2000), 1346.

${ }^{35} \mathrm{Abu}$ Abdillah Muhammad bin Ahmad bin Abu Bakar alQurtuby, Tafsìr al-Qurtuby, vol. 15 (Beirut: Muassasah Risalah, 2006), 339-340.
}

leading interpreters, explains various important things related to the verse above. First, what is called by qawa'id is a woman who has sat down, and is no longer menstruating. That is, the woman has no interest in the opposite sex, her desire has been extinguished. However, the important thing that the author underlines from Hamka's statement is that he considers the interest of a man when looking at women. Women are allowed to take off their outerwear because there are no men who are interested in seeing some of their body parts. So, the benchmark is the attraction of the opposite sex. ${ }^{36}$ As for Imam Nawawi, the term qawa'id not only refers to women who have not menstruated or gave birth, but the word also refers to women who are already weak. In addition, he also no longer needs to get married because of his old age. ${ }^{37}$

In the next section, Hamka explains in detail about the viewpoints of the muslim scholars regarding aurah and its relevance to the Indonesian context. According to his view, half of all scholars say that a woman's entire body is aurah, meaning that all of them carry attractiveness. Therefore, it is necessary for them to wear modest clothing, both with outerwear and undergarments. As for the Indonesian context, what is called outerwear is a scarf covering the head. Hamka added that this verse describes the clothes used when going out of the house. Meanwhile, using a coat (outer dress) is in the context of Europe and Arab lands. As for Indonesian context, scarves or other clothes no longer need to burden an old woman. More importantly, how he is able to maintain his authority, and be a good example to her offspring and descent. ${ }^{38}$

This is also reinforced when looking at makky and madany aspects. Where the abrogation will probably happen to makky surah. After

\footnotetext{
${ }^{36}$ Abdul Malik Abdul Karim Amrullah, Tafsir al-Azhar, vol. 7 (Singapura: Pustaka Nasional, 1989), 4974.

${ }^{37}$ Muḥammad Nawāwī al-Bantani, Tafsīr Marāḥ Labīd, vol. 2 (Indonesia:Haramaian, 2014), 87.

${ }^{38}$ Abdul Malik Abdul Karim Amrullah, Tafsir al-Azhar, vol. 7 (Singapura: Pustaka Nasional, 1989), 4974.
} 
examining both verses, an-Nūr and az-Zumār are included in the category of madaniyah surah. So, the abrogation could not be applied. In addition, az-Zarkasyi clarifies that he also did not find any verses that were allegedly included in the makky category in both an-Nūr and az-Zumār. ${ }^{39}$ Thus (QS. 24: 60) is a verse that has full authority in establishing the law as a whole. However, in some phrases the verse still requires clarity, regarding the conditions for the perpetrator who can be justified to take off his outerwear, the limits of the permissibility, and the extent to which it is permissible for qawāid minan nisā' ' is still in question.

Based on the description of the various interpretation works, the author concludes that the required permission for a woman to get specialized by the versean yadha 'na șiyābahunna is connected with three conditions. First, qawā'id min an-nisā' which is commonly understood as a woman who is both menopausal or could not menstruate, and also gives birth, is attractive nor interested in the opposite sex. Second, $l \bar{a}$ yarjūna nikāḥan, It can be comprehended as a loss of desire, reluctance, and desperation to marry. Third, it is not intended to display jewelry (ghaira mutabarrijāt bizinah). When these three conditions have been fulfilled by a woman. Then, a woman gets the prerogative to adjust yadha'na siyābahunna, which is attributed to removing jilbāb, qinā' and ridā'.

\section{Correlation (QS. an-Nür [24]: 60) with the limits of aurah, and its cover}

a. The meaning of the term aurah and its limitations according to scholars.

In Gammatical matter, the word aurah derivered from عار-يعور-عـور which means oneeyed, cause of one-eyed, and physical defect or deformity. ${ }^{40}$ Furthermore, referring to the older

${ }^{39}$ Badruddin Muhammad bin Abdullah al-Zarkasyi, Al-Burhān fĩ 'Ulūmil Qur'ān (Kairo: Dārut Turaș), 194

${ }^{40} \mathrm{~A}$. W. Munawwir, Kamus al-Muanawwir Arab Indonesia Terlengkap (Surabaya:Pustaka Progressif, 1997), 985.
Arabic dictionary, lisānul arab, Ibn Mandzūr also interprets the same thing, in which aurah means physical defect or deformit. He added that the word can also be attributed to all things that are bad, both individually and in groups. Therefore, aurah is everything that needs to be covered. ${ }^{41}$ Meanwhile, based on Indonesian dictionary, aurah defined as: the part of body disallowed to uncover, another meaning is naked, and genitals. ${ }^{42}$ Through the grammatical explanation, it can be concluded that the intonation carried by the word aurah is a bad or embarrassing intonation and it is necessary to cover up the embarrassing thing.

Meanwhile, in the context of the Qur'an, the word rooted in عـ ع و ر مَّار has two forms of

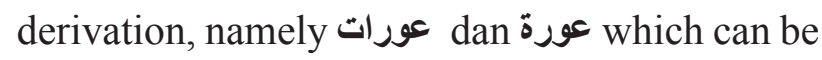
found in three places. The word 'aurāt is: (QS. 24: 58) in which means of closed, or veiled times, the other one is (QS. 24: 31) in which means attached to the female body and it is necessary to be covered. ${ }^{43}$

The term aurah which is repeated twice in (QS. 33: 13) having meaning of defects, shortcomings and weaknesses of fearfully entered by the enemy. Even though, another available meaning is open, as in the following verse:

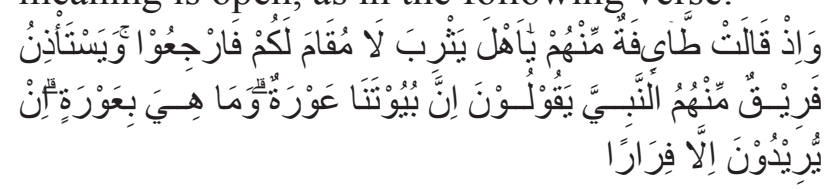

"(Remember) when a group of them said, "O people of Yasrib (Medina), there is no place for you. Then you come back!" Some of them asked the Prophet for permission (to return home) saying, "Verily our houses are open (there are no guards)." In fact, the houses were not open. They just want to run (from the war)".

\footnotetext{
${ }^{41}$ Ibn Mandzur, Lisānul Arab (Kairo: Darul Ma'arif, 1119), 31663167.

${ }^{42}$ Tim Penyusun Kamus Pusat Bahasa, Kamus Bahasa Indonesia (Jakarta: Pusat Bahasa, 2008),104.

${ }^{43}$ Ibrahim Madkur, Mu'jām Alfāz Al-Qur'an al-Karīm (Kairo: Ihya'a at-Turāṣ, 1988), 804.
} 
Based on the information above, it can be seen that the meaning of aurah in the Qur'an is something that is bad or nasty and that needs to be covered up. Thus, this has applied to all mentions of the word aurah with various contexts and derivations in the Qur'an. Both relating to the human body and other contexts.

Many scholars, when mentioning the meaning of aurah inherent in humans, set the limits. At least it can be divided into two parts; in prayer and outside prayer. First, regarding the aurah in prayer. Covering the aurah during prayer is absolute. The meaning of absoluteness here does not depend on the presence of people who see it or not. The same goes for light and dark condition. For the first category, a woman's aurah is all parts of the body except the face and the palms of the hands. ${ }^{44}$ Meanwhile, when related with the freedom horizon, 'ammator slave girl has the same aurah limits as a free man has, which is between the navel to the knee. ${ }^{45}$

Second, regarding the aurah border determined outside of prayer. For this second part, it can be divided into two parts: (1). Aurah for mahram. (2). Aurah for non-mahram. The first view taken from Imam as-Shafi's thought is that the aurah for mahram (husband in exception) is between the navel and the knee, and the aurah for the ajnabiyyah or non-mahram is the entire body. ${ }^{46}$ According to Imam Maliki and Hanafi, the nakedness of mahram is in addition to the head (face and hair), neck, hands up to the elbows and feet up to the knees. As for dealing with an ajnabiyyah, that is, his whole body except his face and hands. This makes the hair, neck, hands up to the elbows, up to the knees must be covered. So, the nature of the aurah in some of these body parts is not fixed, depending on the circumstances, or it can be called aurah aridhi. While the aurah

\footnotetext{
${ }^{44}$ Abdul Mannan, Fiqih Lintas Madzhab, vol. 1 (Kediri: PP. AlFalah, 2009), 91.

${ }^{45}$ Sayyid Muhammad ad-Dimyati, Hasyiyah I'anatut Thalibin, vol. 1 (Bandung: al-Ma'arif), 112.

${ }^{46}$ Ibid., 113.
}

that does not depend on the nature of mahram is called aurah dzati. ${ }^{47}$ Although the other scholars argue that the entire body of a woman is aurah, it is based on (QS. al-Ahzāb [33]: 53) with an emphasis on the word "hijā $b$ ". ${ }^{48}$

The explanation above will be closely related to (QS. 24: 60), even though the verse does not contain the term aurah. The contributing factor is the phrase fa lā junāha an yaḍa 'na șiyābahunna (no sin to undress) regarding to mahram, of course there is no problem taking off the outerwear, but when it linked with ajnabiy, the verse indirectly states the permissibility of uncovering outerwear for some women.

\section{b. Aurah's cover}

It can be clearly discussed from (QS. 24: 60), in which the phrase fa laisa 'alaihinna junahun an yadha'na siyābahunna indicates that the cover is opened. Al-Qurtuby interprets the cover can be opened referring to the word hijāb as well as at-Tabari. But the difference is that al-Qurtuby relates it to khimār, while imam at-Tabari is clearer by describing the terms hijab in question, namely qinā' and ridā' ${ }^{49}$ Through these explanations, these four terms will be explained futher and more detail; jilbāb, khimār, qinā' and ridā'.

The meaning of hijāb in Arabic means clothing that covers the whole body from head to

\footnotetext{
${ }^{47}$ Oktariyadi, "Batasan aurat wanita dalam perspektif hukum Islam", Jurnal Al-Mursalah 2, no, 1 (2016): 23.

${ }^{48} \mathrm{Al}$-Jashash states that the verse indicates that Allah has permitted to ask them (the Prophet's wives) from behind the veil regarding a required need or to ask a question that requires an answer. Women are all nakedness - bodily and in shape-so they are not allowed to open them unless there is an emergency or need, for example to give testimony or because of an illness in their body (for treatment). Regarding this view, the scholars are not very supportive, because in many cases where women can see their limbs, such as when Siti Aisyah led the war. In addition, the conclusion that all women's bodies are awrah is not based on the explicit sound of the text, but rather on the understanding of logic and traditions which were also inseparable from the understanding of the scholars at that time. See: M. Quraish Shihab, Jilbab Pakian Wanita Muslimah: Pandangan Ulama Masa Lalu dan Cendekiawan Kontemporer (Tangerang: Lentera Hati, 2012), 75. ${ }^{49} \mathrm{Abu}$ Abdillah Muhammad bin Ahmad bin Abu Bakar alQurtuby, Tafsvir al-Qurtuby, vol. 15..., 340, cf. Ibn Jarir atThabari, Jamiul bayan an Ta'wil al-Qur'an, vol. 5 (Beirut: Muassasah ar-Risalah), 445.
} 
toe such as abaya used by women in the Middle East today. It doesn't properly mean hijab in Indonesian language..$^{50}$ The word jilbāb means: clothes that cover the clothes and the veil that is being worn, so that the veil becomes like a blanket. Meanwhile, according to al-Biqa'i (1406$1480)$, that the $j i b \bar{a} b$ is a loose garment or veil covering the head of a woman, or clothing that covers her veil that she wears. In other meanings $h i j a \bar{b}$ can also refer to all clothes that cover a woman's body. According to scholars, these meanings can be attributed to term jilbāb. Even if jilbāb is considered a garment, it is a garment that covers the hands and feet; If jilbāb is interpreted as a veil, then the command to extend it is to cover the face and neck. If the meaning is clothes that covers body, then the command to extend it is to make it loose so that it covers all the body and clothes. $^{51}$

While the meaning of khimār linguistically means head covering. Some scholars have added the word face. The addition of the word face is based on the verse wal yadhribna bikhumūrihinna 'alā juyūbihinna "let them cover their khimār to their chests". However, based on Nasruddin alAlbani's examination of the old and new scholars opinions, it was found that the scholars agreed to interpret khimār as a head gear. ${ }^{52}$ So it can be said that the term hijab in Indonesia is more in line with the Arabic term khimār, instead of jilbāb.

The following examined word isqina ', it literally refers to a face cover or veil. In addition, rida' ' is a turban or it can also be called a shawl used by a woman to cover her head and chest. ${ }^{53}$

Based on historical information, that the way women dress, whether free or slave, whether

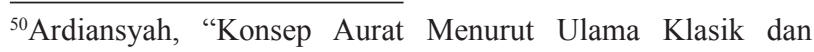
Kontemporer; suatu perbandingan pengertian dan batasannya di dalam dan luar sholat", Analytica Islamica 3, No. 2 (2014): 265.

${ }^{51}$ M. Quraish Shihab, Jilbab Pakaian Wanita Muslimah: Pandangan Ulama Masa Lalu dan Cendekiawan Kontemporer (Tangerang: Lentera Hati, 2012), 88.

${ }^{52}$ Nashruddin al-Albani, Jilbab Wanita Muslimah, translated by. Hidayati (Yogyakarta: Media Hidayah, 2002), 13.

${ }^{53}$ Ema Marhumah, "Jilbab dalam Hadis: Menelusuri Makna Profetik dari Hadis,” Journal Musāwa 13, no. 1 (2014): 61.
}

good or not, is identical. Therefore, nosy men used to harass women, especially those who are known or suspected as slaves. To avoid these disturbances, as well as to show the honor of women, a verse was revealed that ordered to wear the hijab. ${ }^{54}$ So, it can be said maqashid from the obligation to wear clothes, namely: avoiding distractions or maintaining honor. Through the basis of maqashid, the demand for using the hijab cannot be always applied, because qawāid minan $n i s \bar{a}$ ' have no attractiveness and are free from the harassment.

\section{Interpretation (QS. 24: 60); interconnection and contextualization}

The initial foundation that needs to be adhered to is related to the purpose of covering aurah. These points will be a comparison of two things that seem contradictory, namely between cover and uncover the aurah. Or even both are probably compromised (tarjīh), which one can actually be applied in certain situations, and which should be abandoned in other contexts. The purpose of covering the aurah is to avoid slander or maintain honor. Therefore, some scholars, including Ibn Khuwayzī Mandad, asserted based on his ijtihad that even for a very beautiful woman, her face and palms can cause slander, so it is obligatory to cover her face and palms as well. ${ }^{55}$

In surah an-Nūr above, it clearly shows, both based on the explanations of scholars and the results of linguistic analysis, that women are allowed to take off their aurah, by three conditions. First, qawāid minan nisā'. Second, lā yarjūna nikāhan. Third, ghaira mutabarrijāt bi zīnah.

The first requirement, qawāid minan nisā', in the modern era can be contextualized by having ever experienced "menopause". Menopause is defined as the permanent cessation of the

\footnotetext{
${ }^{54}$ M. Quraish Shihab, Jilbab Pakaian Wanita Muslimah: Pandangan Ulama Masa Lalu dan Cendekiawan Kontemporer (Tangerang: Lentera Hati, 2012), 86.

${ }^{55}$ Al-Qurțubī, Tafsir al-Qurțubī, vol. VI (Kairo: Dār al-Sya'b, n.d), 4621
} 
menstrual cycle for women who previously had menstruation as a result of loss of follicleovarian activity. ${ }^{56}$ According to $\mathrm{WHO}$, women who experienced menopause in 2012 worldwide reached 373 million people and it is estimated that it will reach 1.2 billion people by $2030 .{ }^{57}$

The diagnosis of menopause is made after the cessation of menstruation (amenorrhea) for at least one year. Cessation of menstruation can be preceded by a longer menstrual cycle, with less bleeding. The age a woman will experience menopause varies greatly. This is highly dependent on various factors that influence it such as heredity, general health and lifestyle. But it can be said on average a woman will experience menopause around the age of 45 to 50 years. ${ }^{58}$ Thus, if a woman has entered the age of 45 years, then she can be said to fulfill one of the 3 conditions for allowing her to take off her hijāb.

The second condition is that you don't want to get married (lā yarjūna nikahan). That is vaguely purposed for who has lost her lust. Then, the verse use the other expression to represent it by unwillingness to get married. And this point is closely related to women who have entered old age.

The third condition is ghaira mutabarrijātin bizinah (there is no intention of showing jewellery). In the Qur'an, bizinah has several equivalent words, no less than 46 verses in two main forms of derivation, namely: زيّـن "make good, make beautiful/beautiful”, and زينة "everything enables to make beautiful". ${ }^{59}$ Whereas in the context of aurah, it can be interpreted as clothing, or body parts that can stimulate men, except what is usually seen from it or what is seen without the intention to show it. ${ }^{60}$ Thus, the meaning in the

\footnotetext{
${ }^{56}$ Mega Ulfah, "Hubungan Usia dan Lama Menopause dengan Tingkat Kecemasan Wanita Menopause," Journal of Issues in Midwifery 1, no. 1 (2017): 48.

${ }^{57}$ Ibid.

${ }^{58}$ Ibid., 49.

${ }^{59}$ Ibrahim Madkur, Mu'jām Alfāz Al-Qur'an al-Karīm (Kairo: Ihya'a at-Turāș, 1988), 540.

${ }^{60}$ M. Quraish Shihab, Jilbab Pakaian Wanita Muslimah: Pandangan Ulama Masa Lalu dan Cendekiawan Kontemporer (Tangerang: Lentera Hati, 2012), 93.
}

category of yadha'na iyābahunna is the feet, if the body part is not attractive and in general it is used to being seen, so in addition to the head covering, it is also permissible to remove the foot and hand coverings, because in general people who categorized qawāid are allowed to show both parts due to either the attractive and habit reason. This statement is in line with the views of Sheikh Ali Muhammad as-Sais, the feet are not part of aurah. Moreover, the reasoning is based on the masyaqqat "hardship" aspect, precisely because to consistently cover feet is more difficult than the hands. especially for poor women in rural areas who at that time often walked barefoot to look for their needs. ${ }^{61}$

Al-Qurtuby stated through the sentence fa laisa 'alaihinna junāhun 'an yadha'na șiyābahunna ghaira mutabarrijātin bi zīnahbywa uzīla 'anhunna kulfatu at-tahaffuzi al-mut'ibi lahunna "removed from the woman the tiring burden guarding them" ${ }^{62}$ Based on this information, the assumption is that wearing certain clothes can make a person feel heavy, and makes it necessary to uncover them. Thus, it is as if this makes a person to crack outwears that are felt heavy. Based on this, khimār more properly represents in the context (QS. an-Nūr [24]: 60).

There is one additional condition based on the munasabah aspect, which is related to the scope of the permission to take off outerwear. In the munasabah aspect, Salwa MS El-Awa's approach considers coherence and relevance aspects in the text. The meaning of the coherence aspect here is related to everything that is in the text, or something related with grammar. For example: Phrases and elements in the text, pronouns, conjunctions, etc. ${ }^{63}$ The study of coherence relations focuses on the formal relationship

\footnotetext{
${ }^{61}$ Ibid., 135 .

${ }^{62} \mathrm{Abu}$ Abdillah Muhammad bin Ahmad bin Abu Bakar alQurtuby, Tafsīr al-Qurtuby, vol. 15 (Beirut: Muassasah Risalah, 2006),340.

${ }^{63}$ Salwa MS. El-Awa, Textual Relations in the Qur'an; Relevance, Coherence, and Structure (London and New York: Routledge 2006), 26.
} 
between the parts of the text that are the main and important components in the text.

Through reading the relevance aspect, emphasizing on the main puzzle in these verses, it is found that the scope of the qawā'id minan nisā ' allowing to remove the head covering is only in the private sphere, not the public. Because the relevance of verses 58 and 61 also speaks with a private narrative. Moreover, the verse number 58 vividly talks about undressing as well. It' is the additional indicator to discover the link.

Meanwhile, the study of the relation about relevance is not only focused on the expressions spoken in the Qur'an, but also related to the assumptions, information, ideas and thoughts contained in the text. This aspect will be able to unite separate expressions in the coherence aspect. ${ }^{64}$ It also provides a more comprehensive understanding of the qur'anic text. ${ }^{65}$ So, the aspect that is highlighted here is the pragmatic aspect or relevance by considering the grammatical aspect, and if there is a discrepancy between the coherence and relevance relationships, from the two, this study wins the relevance relationship.

Meanwhile, from the coherence aspect or the search for the letter'ataf in these verses, or the search for other grammatical aspects which may be an indication of a relationship with other verses. This coherence clue is found at the beginning of number verse sixty. At the beginning of the wal qawā'idu verse using the letter 'ataf which indicates a relationship with verses 59 and 58. Based on the two results of the analysis, it can be concluded that the intended scope in the narrative is the permission for a woman to take off her aurah, as well as in private or home. However, this does not mean that opening the siyāb is only permissible for mahram. Imam atTabari believes that opening siyābin the verse also means universal or can be done without exception, both to mahrams and non-mahrams,

${ }^{64}$ Ibid., 26

${ }^{65}$ Ibid., 28. as the Thabari's explanation: ${ }^{66}$

$$
\begin{aligned}
& \text { لا حـرج عليهن ان يضعـن ذاللك عند المحار من الرجال و غير } \\
& \text { الحرم عند الغرباء غير متبرجات بزينة }
\end{aligned}
$$

There is no sin for them to undress both in front of mahram and non-mahram.Furthermre, it is also permissible in front of strangers as long as the woman doesn't intend displaying their adornment.

Basically, both the Qur'an and Hadith do not at all want the give the masyaqqah (difficulty). Evidence of this principle, there is a verse that states that women are allowed to open their outer clothes. This is also in line with the rules of $i d z \bar{a}$ dêq $q \bar{a}$ as-syai' ittasa'a (if something has narrowed, that is, it is difficult, then spaciousness or ease is born). So it is not surprising, if there is a permissibility to undress for women who are not already attractive again. This also shows the friendliness of Islam with Islamic congregation.

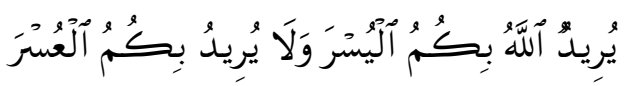

".....Allah intends for you ease and does not intend for you hardship....”. (QS. alBaqarah[2]: 185).

In another verse it is explained

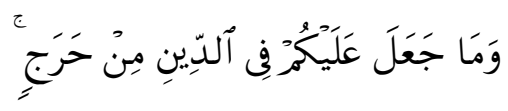

“....He has chosen you and has not placed upon you in the religion any difficulty....". (QS. al-Hajj[22]: 78).

Based on the explanation above, it can be seen that Islam has provided relief for certain women to be able to open the cover of their aurah, with the terms and conditions described above. And this is the result either linguistic analysis and munāsabat al-ayāh. In addition, several points laid on the maqāsī $d$ aspect and also the explanations of the old scholars.

${ }^{66} I$ Ibn Jarir at-Thabari, Jami'ul bayān 'an Ta 'wīl al-Qur'ān, vol. 5 (Beirut: Muassasah ar-Risālah), 446. 


\section{Conclusion}

The disagreement between classical scholars and modern scholars has never been end. Even, we cite madzhāb arba'ah as the main basic of the discussion; Hanafi, Maliki, Syafi'i and Hanbali have their own way to interpret the limit of aurah. Moreover, the core of idea is demanding to cover the aurah, and hardly to find another narration leaving that issue. The classic scholars tend to apply the strict rule in which woman has to covered almost all of the body due to the scriptural reason whereas the contemporaries hugely fight back their opinion due to rational reason. This article has conducted that both of reasons are likely combined through the verses (QS. 24: 58-61). Moreover, the meaning of the text can be easily seen by the textual approaches where the specific woman is allowed to unveil the aurah and the appeared difficulties by fully covering the body have able to be solved.

Munāsabah analysis is used to examine how the required conditions can be accurately applied in this era. Most important thing is to grab the purposed scope of the text. The series of the text (QS. 24: 58-61) tells that the scope is limited for private or local milieu. The beginning of the series contains the need of both servant and the child to ask the permissible before entering the bedroom and the next part is merely talking with the same sense. Then, the conditions needed to the permissibilityare: (1). Have experienced menopause (age 45 years). (2). Has no desire for the opposite sex. (3). Not showing jewelry intentionally. (4). The specific jewelry allowed to be removed is khimār, qinā', or ridā'. (5). The appearing body can not stimulate men. (4). Being in a limited scope, spesifically in the home.

When we compare to numerous articles produced by another scholar, it will be clearly seen that the concern of aurah study always neglect the discussion of legal and non-legal in the sense if unveiling aurah. They have prioritized the aurah limit as the main basis of the study. Arising this study is hoped for discovering others perspective regardless the mainstream topic around the limit and/or the style of hijab. Thus, the upcoming study is possible in scrutinizing the same problem by another perspective.

\section{References}

al-Albani, Nashruddin. Jilbab Wanita Muslimah. Translated by Hidayati. Yogyakarta: Media Hidayah, 2002.

Amrullah, Abdul Malik Abdul Karim. Tafsir al-Azhar. Volume 7. Singapura: Pustaka Nasional, 1989.

Ardiansyah. "Konsep Aurat MenurutUlama Klasik dan Kontemporer; suatu perbandingan pengertian dan batasannya di dalam dan luar sholat." Analytica Islamica 3. No. 2 (2014): 42-62.

Auda, Jasser. Maqāsīd al-Syari'ah as Philosophy of Islamic Law a System Approach. London: Internasional Institute of Islamic Thought, 2007.

al-Bantani, Muhammad Nawāwī. Tafsīr Marāḥ Labīd. Volume 2. Indonesia: Haramain, 2014.

ad-Dimyati, Sayyid Muhammad. Hasyiyah I'anatut Thalibin. Volume 1. Bandung: al-Ma'arif.

Droogsma, Rachel Anderson. "Redefining Hijab: American Muslim Women's standpoints on veiling." Journal of Applied Communication Research 35. No. 3 (2007): 20-42.

El-Awa, Salwa MS. Textual Relations in the Qur'an; Relevance, Coherence, and Structure. London and New York: Routledge, 2006.

Katsir, Ismail bin Umar bin. Tafsīr al-Qur'ānul 'Ażìm. Beirut: Dar ibn Hazm, 2000.

Ma'luf, Luis. Mu'jam al-Munjīd. Libanon: Darul Fikri, n.d.

Mandzur, Ibn. Lisānul 'Arab. Kairo: Darul Ma'arif, $1119 \mathrm{H}$. 
Madkur, Ibrahim. Mu'jām Alfāz al-Qur'ān alKarìm. Kairo: Ihyā' at-Turā--, 1988.

Mannan, Abdul. Fiqih Lintas Madzhab. Volume 1. Kediri: PP. Al-Falah, 2009.

Marhumah, Ema. "Jilbab dalam Hadis: Menelusuri Makna Profetik dari Hadis." Jurnal Musāwa 13. No. 1 (2014): 30-55.

Munawwir, A. W. Kamus al-Muanawwir Arab Indonesia Terlengkap. Surabaya: Pustaka Progressif, 1997.

Nuraini and Dhiyauddin. Islam dan Batas Aurat Wanita. Yogyakarta: Kaukaba, 2013.

Nurul Hikmah binti Nidzam. al-aurah fi fiqhi al-Islami wa atsaruha fil hayātid diniyyah wal ijtimaiyyah. Dissertation of University Islam Sultan Sharif Ali. Faculty of Syari'ah and Islamic law, 2020.

Oktariyadi. "Batasan aurat wanita dalam perspektif hukum Islam.” Jurnal Al-Mursalah 2. No. 1 (2016): 60-65.

Penerbit Kalim. Al-Qur'an Tafsir Per Kata Tajwid dan Kode Angka al-Hidayah. Tangerang Selatan: Kalim, 2011.

al-Qurtuby, Abu Abdillah Muhammad bin Ahmad bin Abu Bakar. Tafsìr al-Qurtuby. Volume 15. Beirut: Muassasah Risalah, 2006.

Ruby, Tabassum F. “The Hijab in Modern Culture." Woman's Studies Internasional Forum 29. No. 1 (2006): 27-50.

ash-Shiddiqy, Teungku Muhammad Hasbi. Tafsir al-Qur'an al-Majid; an-Nuur. Volume 4. Semarang: Pustaka Rizki Putra, 2000.

Shihab, M. Quraish. Jilbab Pakaian Wanita Muslimah: Pandangan Ulama Masa Lalu dan Cendekiawan Kontemporer. Tangerang: Lentera Hati, 2012.
. Tafsir al-Mishbah. Volume 3. Jakarta: Lentera Hati, 2005.

as-Shobuni, Muhammad Ali. Rawāi'ul Bayān; Tafsīr Ayāt al-Ahkām. Volume 3. Damaskus: Maktabah al-Ghazali, 1980. Sulaiman, Muqatil bin. Tafsīr Muqātil bin Sulaimān. Volume 3. Beirut: Muassasah Tarikh al-Araby, 2002.

Syahrur, Muhammad. Nahwa Ușūl Jadīdah li al-Fiqh al-Islāmy. Mesir: al-Ahāli, 2000. .al-Kitāb wal Qur'ān: Qirā'ah Muașirah. Damaskus: al-Ahaly, 2013.

Syarkawi, "Studi Kritis Terhadap Pemikiran M. Quraish Shihab Tentang Aurat Wanita dan Jilbab yang Bertentangan dengan Empat Mazhab." Journal Al-Qira'ah 14. No. 2 (2020).

as-Syatibi, Abu Ishaq. al-Muwafaqat fi Ushul al-Syari'ah. Beirut: Darul Ma'rifah, 1997.

at-Thabari, Ibn Jarir. Jamī'ul Bayān 'an Ta'wīl al-Qur'ān. Volume 5. Beirut: Muassasah ar-Risalah.

Tim Penyusun Kamus Pusat Bahasa. Kamus Bahasa Indonesia. Jakarta: Pusat Bahasa, 2008.

Ulfah, Mega. "Hubungan Usia dan Lama Menopause dengan Tingkat Kecemasan Wanita Menopause." Jurnal of Issues in Midwifery 1. No. 1 (2017): 150-177.

Zanirah Mustafa, et.al. "The concept of aurah: Islamic dressing code and personal grooming according to fiqh law." E-Academia Journal 7. No. 2 (2018): 210-232.

az-Zarkasyi, Badruddin Muhammad bin Abdullah. Al-Burhān fì Ulūmil Qur'ān. Kairo: Dārut Turāṣ. 